1 Dixon MF. Campylobacter pylori and chronic gastritis. In: Rathbone BJ, Heatley RV, eds. Campylobacter pylori and gastroduodenal disease. Oxford Blackwell Scientific Publications, 1989:106-16.

2 Sipponen P, Kekki M, Siurala M. Precancerous conditions. In: Filipe MI, Jass JR, eds. Gastric carcinoma. Edinburgh: Churchill Livingstone, 1986:152-71

3 Correa P, Ruiz B. Campylobacter pylori and gastric cancer. In: Rathbone BJ Heatley RW, eds. Campylobacter pylori and gastroduodenal disease. Oxford Blackwell Scientific Publications, 1989:139-45.

4 The Gastrointestinal Physiology Working Group. Helicobacter pylori and gastritis in Peruvian patients: relationship to socioeconomic level, age and sex. Am f Gastroenterol 1990;85:819-23.

5 Perez-perez GI, Taylor DN, Bodhidatta L, Wongsrichanalai J, Baze WB Dunn BE, et al. Seroprevalence of Helicobacter pylori infections in Thailand. $\mathcal{F}$ Infect Dis 1990;161:1237-41.

6 Fox JG, Correa P, Taylor NS, Zavala D, Fontham E, Janney F, et al. Campylobacter pylori-associated gastritis and immune response in a population at increased risk of gastric carcinoma. Am $\mathcal{f}$ Gastroenterol 1989;84:775-81.

7 Forman D, Sitas F, Newell DG, Stacey AR, Boreham J, Peto R, et al. Geographic association of Helicobacter pylori antibody prevalence and gastric cancer mortality in rural China. In $f$ Cancer 1990;46:608-11.

8 Robey-Cafferty SS, Ro JY, Cleary KR. The prevalence of Campylobacter pylori in gastric biopsies from cancer patients. Modern Pathology 1989;2: pylori $473-6$.

9 Feng Y, Wang Y. Campylobacter pylori in patients with gastritis, peptic ulcer and carcinoma of the stomach in Lanzhou, China. Lancet 1988; $\mathrm{i} 1055-6$.

10 Jaskiewicz K, Louwrens HD, Woodroof LW, Van Wyk MJ, Price SK. The association of Campylobacter pylori with mucosal pathological changes in population at risk for gastric cancer. $S$ Afr Med J 1989;75:417.9.

11 Wald N, Idle M, Boreham J, Bailey A. Low serum vitamin A and subsequent risk of cancer: preliminary results of a prospective study. Lancet 1980;ii: 813-5.

12 The Caerphilly and Speedwell Collaborative Group. Caerphilly and Speedwell collaborative heart disease studies. $f$ Epidemiol Community Health 1984;38: 259-62.

13 Steer HW, Hawtin PR, Newell DG. An ELISA technique for the serodiagnosis of Campylobacter pyloridis infection in patients with gastritis and benign duodenal ulceration. Serodiagnosis and Immunotherapy 1987;1:253-9.
14 Talley NJ, Newell DG, Ormand JA, Carpenter HA, Wilson WR, Zinsmeister AR, et al. Serodiagnosis of Helicobacter pylori: a comparison of enzyme linked immunosotbent assays. 1 Clin Microbiol (in press).

15 Breslow NE, Day NE. Statistical methods in cancer research. Vol 1. The analysis of case-control studies. Lyons: International Agency for Research on Cancer,

16 Kwa G, Cleton F, Wang DY, Bulbrook RD, Bulstrode JC, Hayward JL, et al. Prospective study of plasma prolactin levels and subsequent risk of breas cancer. Br J Cancer 1981:28:673-6.

17 Talley NJ, Dimagno E, Zinsmeister AR, Perez-perez G, Blaser M. Helicobacter pylori and gastric cancer: a case-control study [abstract]. Revisto Espanola de Enfermedades Digestivas 1990;78 (suppl 1):7-8.

18 Yang PC, Davis S. Epidemiological characteristics of adenocarcinoma of the gastric cardia and distal stomach in the United States, 1973-82. Int $\mathcal{J}$ Epidemiol 1988;17:293-7.

19 Howson CP, Hiyama T, Wynder EL. The decline in gastric cancer: epidemiology of an unplanned triumph. Epidemiol Rev 1986;8:1-27.

20 Logan WPD. Cancer mortality by occupation and social class 1851-1971. London: HMSO, 1982. (Studies on Medical and Population Subjects, No 44.)

21 Barker DJP, Coggon D, Osmond C, Wickham C. Poor housing in childhood and high rates of stomach cancer in England and Wales. Br $\mathcal{Y}$ Cancer and high rates

22 Siurala M, Sipponen P, Kekki M. Campylobacter pylori in a sample of the Finnish population: relations to morphology and function of gastric mucosa. Gut 1988;29:909-15.

23 Paull G, Yardley JH. Pathology of $\mathrm{C}$ pylori-associated gastric and esophageal lesions. In: Blaser MJ, ed. Campylobacter pylori in gastritis and peptic ulcer disease. New York: Igaku-Shoin, 1989:73-97.

24 Sitas F, Forman D, Yarnell JWG, Burr ML, Elwood PC, Pedley S, et al. Helicobacter pylori infection rates in relation to age and social class in a population of Welsh men. Gut 1991;32:25-8.

25 Marshall BJ. Campylobacter pylori: its link to gastritis and peptic ulcer disease. Rev Infect Dis 1990;12 (suppl 1):S87-93.

(Accepted 17 April 1991)
Gastrointestinal Unit and Surgical Review Office, Western General Hospital, Edinburgh EH4 2XU D M Sedgwick, FRCS, research fellow

J A Akoh, FRCs, surgical registrar

I M C Macintyre, FRCS, consultant surgeon

Correspondence to: Mr Macintyre.

BMF 1991;302:1305-7

\section{Gastric cancer in Scotland: changing epidemiology, unchanging workload}

\author{
D M Sedgwick, J A Akoh, I M C Macintyre
}

\section{Abstract}

Objective-To determine the changes in incidence of and mortality from gastric cancer in Scotland between 1978 and 1987 and in the operative workload in Lothian between 1979 and 1988.

Design-Analysis of national incidence statistics for gastric cancer derived from the Scottish national cancer registry, deaths from gastric cancer recorded by the registrar general for Scotland, and Lothian surgical audit data.

Setting-Scotland and Lothian Health Board area.

Patients - Patients in Scotland with gastric cancer during 1978 to 1987 inclusive; patients in Scotland with gastric cancer recorded on their death certificate as cause of death during 1978 to 1987 ; patients who had an operation in Lothian for gastric cancer during 1979 to 1988.

Main outcome measures-Changes in incidence of and mortality from gastric cancer in Scotland from 1978 to 1987 and in the number of operations performed for gastric cancer in Lothian from 1979 to 1988.

Results - Mortality from gastric cancer in Scotland fell by about $25 \%$ over the 10 years. The incidence and standardised incidence of gastric cancer showed a marginal decline of about $9 \%$. The differences in trends between incidence and mortality were significant $(p<0.05)$.

Conclusions - This study shows that the surgical workload associated with gastric cancer is not declining. This is because the incidence has remained almost static, which may be due to the relative increase in the numbers of older people in the population, who are at greater risk of developing gastric cancer. Gastric cancer should not be regarded as a disease in decline. Incidence and workload should determine resources allocated to this disease rather than mortality statistics.

\section{Introduction}

Since the 1940s mortality from gastric cancer has been falling throughout the world. This has been particularly pronounced in countries such as Finland and the United States, where, by the 1980s, the annual age adjusted mortality had fallen by $73 \%$ and $66 \%$ respectively compared with 30 years earlier.' The incidence of gastric cancer has also been reported to be falling. ${ }^{24}$ These statistics have led to gastric cancer being viewed as a disease in decline. However, the numbers of patients in our practice with gastric cancer do not seem to be declining. ${ }^{6}$

We examined the surgical workload associated with gastric cancer in our area, the trends in the incidence of and mortality from gastric cancer in Scotland, and the implications of these data for health care provision.

\section{Methods}

In Lothian Health Board details of all general operations have been recorded since 1977 in the Lothian surgical audit scheme. ${ }^{7}$ For each procedure the surgeon codes the organ concerned, the disease process, and the nature of the operation. We examined data for 1979-88 on gastric cancer to determine the number of operations each year.

We abstracted data on the incidence of gastric cancer during 1978-87 from Scottish national cancer registration scheme records, which are held by the information and statistics division of the Scottish Health Services Common Services Agency. Population based regional registries in Edinburgh, Glasgow, Dundee, Aberdeen, and Inverness contribute data to 
the national scheme. Registration information is obtained from hospital records, hospital discharge summaries (Scottish morbidity record forms), pathology reports, and death certificates.

Mortality data, in the form of numbers of deaths by sex and five year age bands, for 1978 to 1987 were extracted from annual reports of the registrar general for Scotland. ${ }^{8}$ Mid-year estimates of the population of Scotland in the same groupings of sex and age were also drawn from this source.

Both incidence and mortality data are presented as age and sex standardised rates calculated by the direct method and standardised with the world standard population. ${ }^{9}$ Simple linear regression of rates on year of registration or death was used to evaluate time trends. ${ }^{10}$

\section{Results}

The impression from our practice that surgical workload for gastric cancer was not declining was confirmed by Lothian surgical audit statistics. For the 10 years from 1979 to 1988 (table I) there was no overall decline in the number of operations for gastric cancer, with 81 performed in 1979 and 94 in 1988. Similarly, for Scotland as a whole the incidence of gastric cancer recorded by the Scottish national cancer registration scheme between 1978 and 1987 did not change significantly either in total or for each sex (fig 1). Furthermore, there was no relative change in the incidence or in the sex ratio in people aged over 65 (fig 1). When these data were standardised the incidence showed a marginal decline (fig 2). The average annual decline for men of $0 \cdot 23 / 100000$ just reached significance $(95 \%$ confidence interval -0.44 to $-0 \cdot 22$ ), while that of $0 \cdot 1 / 100000$ for women was not significant $(-0.29$ to 0.08$)$.

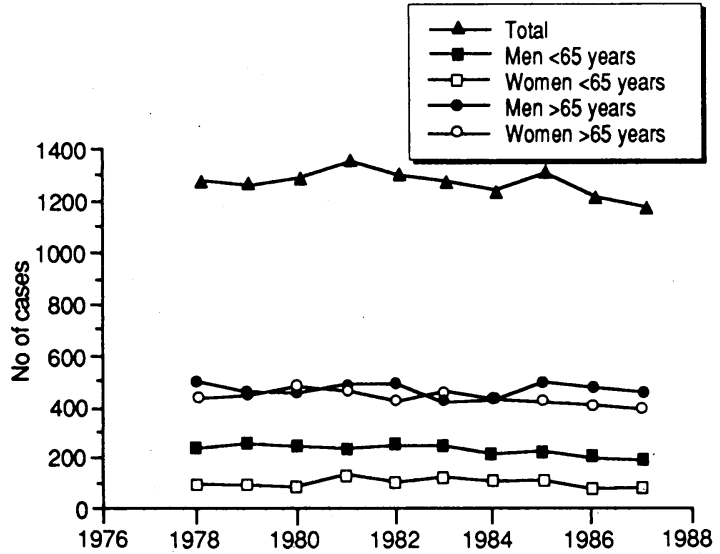

FIG $1-$ Total and age and sex specific incidences of gastric cancer recorded by Scottish national cancer registration scheme, 1978-87

TABLE I - Number of major operations for gastric cancer performed in Lothian Health Board area, 1979-88

\begin{tabular}{lcccccccccc}
\hline & 1979 & 1980 & 1981 & 1982 & 1983 & 1984 & 1985 & 1986 & 1987 & 1988 \\
\hline No of resections & 67 & 65 & 63 & 67 & 61 & 52 & 62 & 69 & 44 & 58 \\
No of other operations & 14 & 29 & 35 & 38 & 49 & 23 & 35 & 25 & 33 & 36 \\
\hline Total & 81 & 94 & 98 & 105 & 110 & 75 & 97 & 94 & 77 & 94 \\
\hline
\end{tabular}

TABLE II - Deaths from gastric cancer ${ }^{\star}$ recorded by registrar general and regression coefficients $(b)$ for trends over time in Scotland, 1978-87

\begin{tabular}{|c|c|c|c|c|c|c|c|c|c|c|c|c|}
\hline & \multicolumn{10}{|c|}{ Year } & \multirow[b]{2}{*}{ b } & \multirow{2}{*}{$\begin{array}{l}95 \% \text { Confidence } \\
\text { interval }\end{array}$} \\
\hline & 1978 & 1979 & 1980 & 1981 & 1982 & 1983 & 1984 & 1985 & 1986 & 1987 & & \\
\hline $\begin{array}{l}\text { len } \\
\text { omen }\end{array}$ & $\begin{array}{l}657 \\
521\end{array}$ & $\begin{array}{l}631 \\
494\end{array}$ & $\begin{array}{l}591 \\
497\end{array}$ & 605 & 626 & $\begin{array}{l}535 \\
468\end{array}$ & $\begin{array}{l}521 \\
449\end{array}$ & $\begin{array}{l}551 \\
459\end{array}$ & $\begin{array}{l}519 \\
442\end{array}$ & $\begin{array}{l}561 \\
424\end{array}$ & $\begin{array}{r}-13 \cdot 28 \\
-9 \cdot 17\end{array}$ & $\begin{array}{l}-20.93 \text { to }-5.62 \\
-13.47 \text { to }\end{array}$ \\
\hline Total & 1178 & 1125 & 1088 & 1095 & 1057 & 1003 & 970 & 1010 & 961 & 985 & $-22 \cdot 45$ & $-29 \cdot 53$ to $-15 \cdot 36$ \\
\hline
\end{tabular}

*International Classification of Diseases code 151.

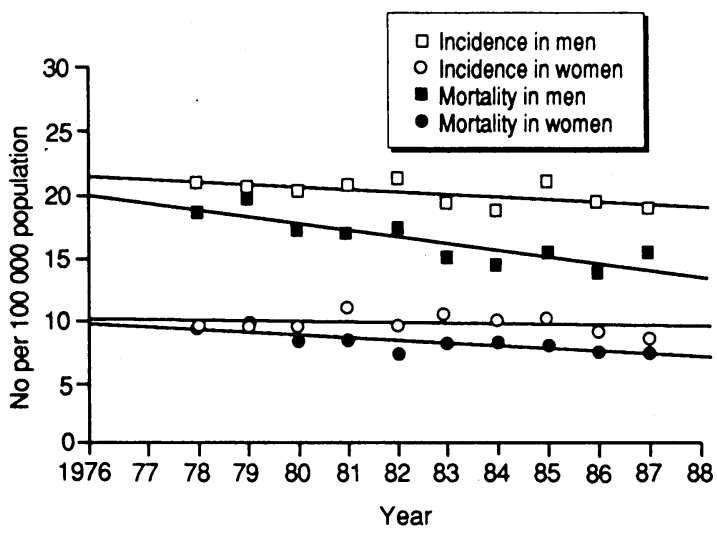

FIG 2-Standardised incidence of and mortality from gastric cancer in Scotland, 1978-87

Mortality, however, fell significantly in both sexes. The number of deaths recorded by the registrar general for Scotland (table I) fell from 1178 in 1978 to 985 in 1987. Standardised mortality (fig 2 ) showed an average annual decline of $0.59 / 100000$ for men $(-0.84$ to $-0 \cdot 34)$ and $0 \cdot 25 / 100000$ for women $(-0.36$ to $-0 \cdot 14)$ Thus while the incidence was estimated to have fallen by $10 \%$ in men and $9 \cdot 2 \%$ in women over the 10 years studied mortality in the same period fell by $28 \%$ and $25 \%$ respectively. In both men and women the differences in trends between incidence and mortality were significant $(\mathrm{p}<0 \cdot 05)$.

\section{Discussion}

The incidence of gastric cancer each year remained almost steady over the past 10 years from 1978 to 1987 in Scotland, according to data derived from the national cancer registry. This has implications for clinicians and service managers, who may have been led to believe that the incidence of stomach cancer is declining and will make less demands on clinical services.

Factors that can affect the number of cancers recorded include changes in population size and structure, in the risk of developing the disease, in the ascertainment of cases, and in registration. To try to tease out the effects of the different factors linear regression lines were fitted to incidence values and populations for each age and sex group for 1978 to 1987 (table III). These give a rough indication of the average trends over the decade.

The Scottish population fell from 5212300 in 1978 to 5112129 in $1987 . .^{8}$ At the same time the age distribution changed. There were reductions in the numbers of people aged less than 40 and in those aged between 50 and 69 . There was an increase in the 40 to 49 age group and in those aged 70 and over, with the over 80 age group showing the most pronounced absolute increase. The overall effect was a proportionate increase in the number of older people, in whom the risk of cancer is higher.

Table III shows that the risk of developing cancer has fallen only marginally in men in all age groups, and in none did the decline reach significance. As a consequence the increasing proportion of the population in high risk age groups means that the number of new cases has remained static.

In women the rates showed a tendency to fall in all except those aged 55 to 64 . In the age group 75 to 84 the decrease was significant. However, the modest declines in risk to individual women together with increasing proportions of the female population in the high risk age groups has meant that the incidence has remained stable.

Diagnosis of gastric cancer is likely to have improved as a result of the increasingly widespread use of 
TABLE III-Age specific incidence and regression coefficients $(b)$ for trends over time for gastric cancer in Scotland, 1978-87

\begin{tabular}{|c|c|c|c|c|c|c|c|c|c|c|c|c|}
\hline \multirow{2}{*}{$\begin{array}{l}\text { Age } \\
\text { group }\end{array}$} & \multicolumn{10}{|c|}{ Year } & \multirow[b]{2}{*}{ b } & \multirow{2}{*}{$\begin{array}{l}\text { 95\% Confidence } \\
\text { interval }\end{array}$} \\
\hline & 1978 & 1979 & 1980 & 1981 & 1982 & 1983 & 1984 & 1985 & 1986 & 1987 & & \\
\hline \multicolumn{13}{|c|}{ Men } \\
\hline $35-44$ & $3 \cdot 4$ & $7 \cdot 1$ & $3 \cdot 7$ & $4 \cdot 4$ & $6 \cdot 1$ & $3 \cdot 2$ & 3.4 & $5 \cdot 2$ & $4 \cdot 2$ & $1 \cdot 8$ & -0.20 & -0.52 to 0.13 \\
\hline $45-54$ & $21 \cdot 6$ & $23 \cdot 2$ & $29 \cdot 7$ & $25 \cdot 0$ & $25 \cdot 2$ & $21 \cdot 4$ & $23 \cdot 2$ & $24 \cdot 0$ & $16 \cdot 3$ & $18 \cdot 5$ & $-0 \cdot 70$ & -1.41 to 0.6 \\
\hline $55-64$ & $65 \cdot 4$ & $66 \cdot 4$ & $61 \cdot 9$ & $64 \cdot 6$ & $64 \cdot 9$ & $72 \cdot 1$ & $60 \cdot 4$ & $62 \cdot 6$ & $64 \cdot 4$ & $62 \cdot 7$ & -0.24 & -0.94 to 0.47 \\
\hline $65-74$ & $147 \cdot 8$ & $132 \cdot 5$ & $136 \cdot 4$ & $150 \cdot 9$ & $164 \cdot 9$ & $131 \cdot 6$ & $127 \cdot 5$ & $150 \cdot 7$ & $145 \cdot 4$ & $136 \cdot 9$ & -0.24 & -2.87 to 2.39 \\
\hline $75-84$ & $216 \cdot 6$ & $245 \cdot 3$ & $222 \cdot 7$ & $230 \cdot 0$ & $211 \cdot 4$ & $209 \cdot 7$ & $226 \cdot 8$ & 238.9 & $227 \cdot 9$ & $210 \cdot 5$ & $-3 \cdot 1$ & -3.45 to 2.83 \\
\hline \multicolumn{13}{|c|}{ Women } \\
\hline $35-44$ & $3 \cdot 3$ & 1.7 & $2 \cdot 3$ & $5 \cdot 3$ & 1.9 & $3 \cdot 7$ & $2 \cdot 2$ & $1 \cdot 8$ & $1 \cdot 8$ & $2 \cdot 1$ & $-0 \cdot 12$ & -0.38 to 0.14 \\
\hline $45-54$ & $10 \cdot 3$ & $8 \cdot 8$ & 8.9 & $10 \cdot 6$ & $10 \cdot 0$ & $12 \cdot 4$ & $8 \cdot 8$ & $9 \cdot 2$ & $7 \cdot 2$ & $6 \cdot 2$ & $-0 \cdot 30$ & -0.63 to 0.03 \\
\hline $55-64$ & $20 \cdot 2$ & $22 \cdot 4$ & $20 \cdot 6$ & $32 \cdot 4$ & $26 \cdot 2$ & $28 \cdot 0$ & $31 \cdot 0$ & $32 \cdot 7$ & $22 \cdot 9$ & $25 \cdot 6$ & $0 \cdot 67$ & -0.31 to 1.65 \\
\hline $65-74$ & $70 \cdot 9$ & $73 \cdot 0$ & 68.9 & $72 \cdot 4$ & $64 \cdot 5$ & $64 \cdot 5$ & $68 \cdot 2$ & $64 \cdot 6$ & $71 \cdot 6$ & $57 \cdot 5$ & $-1 \cdot 00$ & -1.86 to -0.14 \\
\hline $75-84$ & $130 \cdot 2$ & $134 \cdot 6$ & $141 \cdot 8$ & $134 \cdot 7$ & $114 \cdot 7$ & $139 \cdot 1$ & $131 \cdot 4$ & 121.9 & $103 \cdot 2$ & $108 \cdot 2$ & -3.05 & $-5 \cdot 25$ to -0.86 \\
\hline
\end{tabular}

*International Classification of

Diseases code 151 . fibreoptic endoscopy. Investigation and treatment of gastric cancer in elderly people has almost certainly increased as confidence has grown in the safety of surgery in elderly people. Ascertainment of cases may therefore have improved. There is no reason to believe that registration of cases changed significantly during the study. The underlying risk of developing cancer may be falling, but the effect of this may be partly hidden by increasing ascertainment. The changes in incidence are, however, offset almost completely by the aging of the population.

The steady incidence in Scotland as a whole is further emphasised in Lothian Health Board (population about 750000 ), where the surgical workload has remained unchanged despite no obvious change in referral patterns and indications for operative intervention.

We have confirmed in this study a decline in mortality from gastric cancer in Scotland which is consistent with that reported from other areas of the world ${ }^{12}$-a decline which is emphasised when the data are standardised (fig 2). Several factors may have influenced this decline.

Firstly, there is evidence that the shortfall between incidence and mortality may be due to improved prognosis as a result of treatment. Two of us have shown a significant decline in operative mortality from gastric cancer in the past 30 years. " Evidence from Japan, ${ }^{5}$ Birmingham, ${ }^{4}$ and our unit ${ }^{6}$ suggests that earlier diagnosis and more radical and safer surgery can produce increased survival at five years.

The decline in mortality might also be explained in part by gastric cancer having become a less fashionable diagnosis when certifying the cause of death-for example, in elderly patients with a wasting illness in whom investigation is considered to be inappropriate.

There may be anomalies in certification of death. For example, in our own series of patients with histologically confirmed gastric cancer $11 \%$ (29 out of 255) who died and had gastric cancer mentioned in the death certificate did not have gastric cancer given as their cause of death under the International Classification of Diseases coding conventions and were thus excluded from mortality statistics. ${ }^{6}$ While this does not necessarily mean that certification of death has been inaccurate, it highlights one of the problems of using it as an epidemiological tool. There is insufficient evidence, however, to suggest that such inaccuracies changed over the 10 year study period.
Gastric cancer has carried such a poor prognosis that mortality has been equated to incidence and used as the principal yardstick of the disease. ${ }^{23}$ Our study showed a significant difference between incidence and mortality. By the end of the study incidence exceeded mortality by $28 \%$ in men and $20 \%$ in women. We would recommend, therefore, that incidence rather than mortality should be used as the prime indicator of the community load of this disease when allocating resources.

The widespread perception of gastric cancer as a disease in decline can largely be attributed to falling mortality. ${ }^{1}$ The availability of mortality data over long periods in many countries means that these have been favoured by epidemiologists in describing trends over time and international variations. ${ }^{12}$ The discrepancies found in this study between mortality statistics on the one hand and incidence and workload statistics on the other, however, raise doubts about the perception of gastric cancer as a disease in decline. Furthermore, they call into question the use of mortality data for planning health care provision. The number of patients with gastric cancer presenting to clinicians in our area is not declining, and services and resources should be allocated in recognition of this. We agree with Boyle that services need to be provided primarily to meet the diagnostic therapeutic needs of living patients with cancer rather than merely to predict the absolute lack of health in only a proportion of this number. ${ }^{13}$ Furthermore, the increasing health expectations of the aging population demand that they should have access to services not only for diagnosis of gastric malignancy but also for its radical treatment as this becomes safer and more effective.

We thank Dr J A Clarke, Mr R J Black, Mrs J Warner, and the staff of the Information and Statistics Division of the Common Services Agency for their help. We also thank Mr S J Nixon and the Lothian surgical audit committee for allowing access to data on workload.

1 Howson CP, Hiyama T, Wynder EL. The decline in gastric cancer: epidemiology of an unplanned triumph. Epidemiol Rev 1986;8:1-27.

2 Waterhouse JAH. Epidemiology of gastric cancer. In: Preece PE, Cuschieri A, Wellwood JM, eds. Cancer of the stomach. London: Grune and Stratton, 1986:1-32.

3 Coggon D, Acheson ED. The geography of cancer of the stomach. BrMed Bull 1984;40:335-41.

4 Allum WH, Powell DJ, McConkey CC, Fielding JWL. Gastric cancer: a 25 year review. Br $\mathcal{F}$ Surg 1989;76:535-40.

5 Hisamichi S. Screening for gastric cancer. World f Surg 1989;13:31-7.

6 Akoh JA, Sedgwick DM, Macintyre IMC. Improving results in gastric cancer-an 11 year audit. Brf Surg 1991;78:349-51.

7 Gruer R, Gordon DS, Gunn AA, Ruckley CV. Audit of surgical audit. Lancet 1986;i:23-6.

8 Registrar General Scotland. Annual report 1989. Part 1: Mortality statistics. Edinburgh: HMSO, 1990

9 Waterhouse JAH, Muir C, Shanmugaratnam K, Powell J, eds. Cancer incidence in five continents. Vol 4. Lyons: International Agency for Research on Cancer, 1982.

10 Armitage P, Berry G. Statistical methods in medical research. 2 nd ed. London: Blackwell Scientific Publications, 1987.

11 Macintyre IMC, Akoh JA. Improving survival in gastric cancer: a review of operative mortality in English language publications from $1970 . \mathrm{Br} \mathcal{J}$ Surg (in press).

12 Doll R, Peto $R$. The causes of cancer: quantitative estimates of avoidable risks of cancer in the United States today. Fournal of the National Cancer Institute 1981;66;1191-308.

13 Boyle P. Relative value of incidence and mortality data in cancer research. In: Boyle P, Muir CS, Grundmann E, eds. Results in cancer research. Berlin: Springer-Verlag, 1989:41-63.

(Accepted 18 April 1991) 